\title{
The 'coming-out' of a hero: The character of Esther in LXX-Esther revisited
}

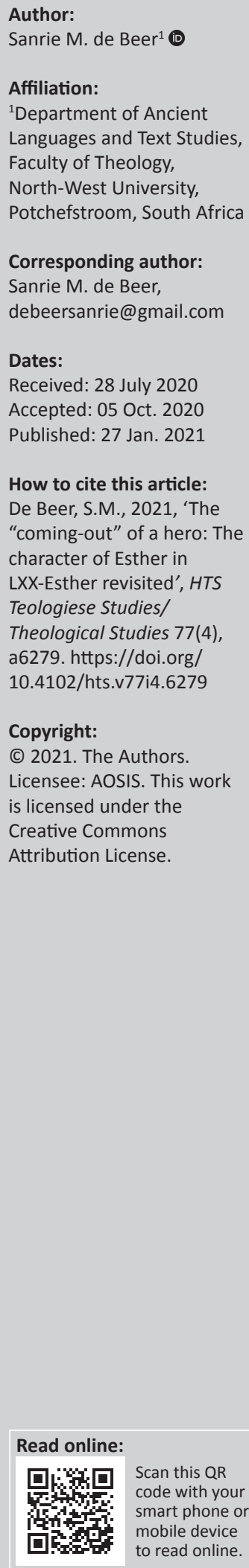

The account of the hero is often depicted as a narratological journey which, with reference to the ground-breaking work of Campbell (2008), is referred to as the monomyth. The basic outline of all monomyths is an account of how a hero embarks on a journey, meets a major crisis and then returns back home altered in some way. This change does not only benefit the hero but is also to the advantage of the community that he or she hails from. This study examines the possibility that the story of Esther fits the prerequisites of a monomyth and argues that the additions (Additions A, B, C, D, E and F) to LXX-Esther give emphasis to and reinforce the impression of the hero-myth underlying the story. The therapeutic and transforming qualities of the hero story, narrated in LXX-Esther, are examined in more detail. It is concluded that this hero story fulfils two basic human functions: an epistemic function and a restorative function.

Contribution: This article contributes to HTS Teologiese Studies/Theological Studies's' contested Historical Thought and Source Interpretation by focusing on textual and hermeneutical studies, and narratives behind the Abrahamic religion as expressed in the Hebrew Scriptures, Apocrypha, Pseudepigrapha and the Septuagint.

Keywords: LXX-Esther; monomyth; Judaism; hero myth; initiation rite.

\section{Introduction}

Our lives are made of stories: stories handed down from our parents, stories we have created out of our experience, stories about our loves, our words, our explorations, our joys, our disappointments, our learning the soul's story. By creating stories, we create and re-create ourselves. (Albert 1996:ix)

At times we need inspiration to restore and re-story our own lives. Using text as narrative texts opens up a multitude of possibilities. Epson and White (1992:89-91), as well as Semeschuk (2018:31-32), point out that when individuals spontaneously recap the content of a favourite story, it functions as a safe vehicle for them to reflect on their own lives, experiences and emotions that have been marginalised. This literal metaphor is a novel or story that has been identified as 'a good story' and can therefore be integrated into a person's experiences and knowledge.

I consider the so-called B-text of Esther (Gardner 1984:1-3; Jobes 1996:1) as a good, healing and life-changing story. A superficial reading of the LXX-Esther ${ }^{1}$ contributes to the impression that the character of Esther is depicted as a hero in a typical monomyth. The account of the hero is often seen as a narratological journey which, with reference to the ground-breaking work of Campbell (2008), is now referred to as the monomyth. The basic outline of all monomyths is an explanation of how a hero embarks on a journey, meets a major crisis and then returns back home altered in some way. This change does not only benefit the hero but is also to the advantage of the community that he or she hails from.

Recent studies focusing on the LXX and considering the literal aspects of these texts:

- Accentuated the story of Joseph (Balkaran 2017:96-104), 3 Maccabees (Allen 2019:1-6) and Judith (Efthimiades-Keith 2012:1-9) as monomyths.

- Hinted on Esther as a possible heroine by comparing the 'beautiful but tough' LXX-Esther, Judith and Susanna (Branch 2014:1-9; Jordaan 2009:1-6; Steyn 2008:156-81).

- Read Susanna (Jordaan 2008:114-128) and 2 Maccabees 6:18-7:42 (Jordaan 2018:3-21) from a narrative therapeutic perspective. The dominant and alternative narratives were discussed. Consequently, the healing and transforming results of these stories were highlighted.

1.See Septuaginta (ed. Rahilfs 1979) 
- Analysed Esther's 'coming out' as a Jew and used it as a model to describe the 'coming-out' process of gays and lesbians (Bahar 2012:167-78; Beal 1997; Berman 2001:647-69; Sedgewick 1990).

\section{Expectations of the journey with Esther}

Studies on the LXX thus exposed the possibility of the hero myth as a topos. Although the character of Esther is often referred to as a hero, no study so far has attempted to compare the portrayal of the character of Esther to the structure of a typical monomyth. Taking the above-mentioned studies into consideration, this study aims to trace the multidimensional performance of the figure of Esther as presented in the LXX (with a focus on the Additions). According to Fox (1991:269-73), Wills (1995:116-310)2 and White-Crawford (1998:134), the additions add nothing to the dramatic quality of the book and lessen the impact of the heroine Esther. This study endeavours to examine the probability that the story of Esther fits the requirements of a monomyth in more detail and, as opposed to the opinions of the above-mentioned scholars, argues that the additions (Additions A, B, C, D, E and F) to LXX-Esther accentuate and reinforce the impression of the hero myth underlying the story of Esther. Furthermore, in what sense can the LXX-Esther be perceived as a healing and restoring text? According to Allison and Goethals (2016:188-90), stories of heroic action divulge wisdom by presenting mental scripts for how one could and should lead one's life. How might the script written by the character of Esther be read from this point of view?

Premingher and Greenstein (eds. 1986:225) comment that the most significant effects on our reactions to a story are our expectancies of what the story is supposed to be and do. We bring to our reading certain presuppositions and interpretative approaches. In the light of this remark, it is presumed that the book of Esther is not to be understood as a historical report of affairs. Wills (1995:2) argues that LXXEsther falls within the category of Jewish novels and was recognised as a fiction before being canonised. According to Wills (1995:3-4), the authors of these Jewish novels utilised certain techniques and themes in their works. These include suggestions to history, prominence of place, severe dangers (often to the Jews as a group), the portrayal of emotion and the focus on woman characters. All of these methods and themes mentioned by Wills (1995) can be mapped out in the story of Esther.

Several commentators (Du Toit 2008:77-93; Fox 1991:196; Steyn 2008:158) maintained that Esther is the only character in

2.Both Fox (1991:269-273) and Wills (1995:116-310) offer consideration to in what matter characterisation contours the dynamics of the story of LXX-Esther. Both arrive at the same conclusion. Fox concludes, ' $[t]$ he overall effect of the Addition on character in the Esther story is to minimise its importance. Instead of Israel's future being dependent on one wise man and one brave woman, its history is now a drama which must turn out the way its Author [God] scripted it' (Fox 1991:273). a drama which must turn out the way its Author [God] scripted it' (Fox 1991:273). Wills judges LXX Esther to be a step backwards: ' $[m$ ] ost of the additions to [Greek] Esther ... undercut the bold experiments of Hebrew Esther; the former are more novelistic in some respects but reduce the interrelation of the characters 'voices' [Wilts 1995:130-31]. For Fox and Wills, a noteworthy effect of the additions is the flattening of characters so that the story becomes subject to only one interpretation (Wills 1995:115; cf. Fox 1991:129-30). According to this thesis, as God appears as the central figure in the story, the autonomy of the human characters fades away. the narrative who shows progression and change. Her character is not built around a single trait. Unlikely to have a historical core, the LXX-Esther is a fable abundant with imaginary elements (Fox 1991:131; Hacham 2007:765-785). A creation of folk literature and abundant with tenets echoing the traits of a satirical drama (Du Toit 2008:77-93), the text draws attention to ideological messages conveyed by different figures (Fox 1991:1-3). The Jewish convention of observing Purim in a festive mood with people wearing masks, acting out satirical plays and drinking superfluously, fits the understanding of Esther as a satirical drama. The book of Esther gives the impression of a satire reflecting the fears of Jews living as a marginal group in a mainly non-Jewish society (Du Toit 2008:92).

The obvious route of narrative criticism will be followed, keeping in mind that the narrative should be treated as a whole. It is anticipated that such a comparative study will assist in understanding the extent of the similarities between the classic heroic pattern, the so-called monomyth and LXXEsther.

\section{The monomyth: A metaphor initialising healing and transformation Recognising the monomyth}

Campbell (2008) recognised the stories and myths of global cultures as reflections of a single, collective narrative. This monomyth, a progressive pattern recounting ways for directing people through difficult thresholds of change (Campbell 2008:6), imitates the rites of passage prevailing across time and around the world. Numerous theorists have endeavoured to express the diverse stages that include the typical monomyth structure (Cousineau 2001; Leeming 1981; Van Gennep 1960). For the purposes of this article, the model proposed by Campbell (2008) will be referred to.

In the classic text The Hero with a Thousand Faces (2008), Campbell outlined the monomyth as the hero's journey, a symbolic account of the recurrent processes of (1) separation or departure, (2) initiation, transformation and descent and (3) return.

Taken from studies of global myths, the hero's journey commences with what Campbell (2008:23) labelled as the 'world of common day', the mundane domain in which the hero resides. It is a familiar state of being, an existence that conveys its own securities and strains. Into this life, an awakening appears an occurrence that causes a disruption in the hero's world view and summons the hero to contemplate the prospect of something different.

\section{The first step: The hero's departure or separation}

This appeal to adventure marks the first phase of the hero's journey and implies that fate has called the hero to an unfamiliar zone (Campbell 2008:48). The appeal acts as an 
internal power or an external stimulus. Not every hero instantly rises to meet the challenge, however, and the rejection of the call can lock the hero into an unfulfilling existence. Campbell (2008:49) observed that the refusal often involves a hero's reluctance to forfeit his or her own comforts, a decision that eventually turns the hero into a victim.

Upon accepting the appeal to a quest, the hero meets a supernatural aid, a mentor or ally who unites the hero with the resources essential to endure the journey. With their support, the hero embarks onto the first threshold and leaves behind the familiar to move into the unknown. The hero seems to withdraw from the world submerged in the belly of the whale, where the hero commences to engage in selfreflection with the purpose of resurrection.

\section{The initiation phase: The hero's commencement, conversion and/or descent}

In the initiation phase, the hero encounters various tests and challenges (Campbell 2008:89). The objective of the ordeals is to strengthen the hero. He or she obtains the knowledge to trust allies, rely on his or her own emerging skills and move through the challenges. Attaining apotheosis, the hero has freed himself or herself from the restrictions of his or her initial world view and achieves insight - something substantial or internal (knowledge or wisdom) aids as the incentive for the hero's struggles.

\section{The hero's return}

Often, a hero endeavours to delay the process of reintegration into the ordinariness of daily life. However, life will call and the hero will be forced to cross the return threshold (Campbell 2008:186-187). The hero must endure to go back to the ordinary world, still maintain the acquired self-assurance and learn to accept the ordinariness of daily life again (Campbell 2008:189). This final trial transforms the hero into the 'master of two worlds'. A transformation is attained and the hero is reborn.

\section{The metaphor of the hero's journey: Transformation as well as restoration}

Scholars observing therapeutic theories (Allison \& Goethals 2016:187-209; Lawrence 2009:263-271; Robertson \& Lawrence 2015:264-77) as well as those focusing on the LXX-texts of 3 Maccabees (Allen 2019:1-6) and Judith (Efthimiades-Keith 2012:1-9) have acknowledged the restorative and transforming power of the monomyth. In this regard, the article of Balkaran (2017:96-104) investigating Joseph's journey as a monomyth is similarly acknowledged. Hero's narratives are considered to be effective delivery structures for divulging complexities and for inspiring humans towards a higher emotional and behavioural state. Narrative reports of heroic deeds are the drive for both human endurance and human growth. Campbell's monomythic metaphor of the hero's journey hints that individuals may decide how they react to perplexing life events, consequently connecting with values of self-actualisation and conceptions of spiritual change (Bray 2018:225).

Allison and Goethals (2016:187) state that hero stories fulfil two basic human functions: an epistemic function and a restorative function. The epistemic function denotes the knowledge and wisdom that hero stories convey, whereas the restorative function denotes the inspirational results these stories may bring about.

\section{The story of Esther - A possible hero? \\ Methodology}

The story of Esther narrated in the LXX-Esther will be examined in the light of Campbell's model of departure, initiation and return. The following macrostructure of LXXEsther proposed by $\mathrm{Du}$ Toit (2008:85) will be utilised selectively to highlight the function of the character of Esther in the progression of the story (Table 1).

The Additions to Esther will be taken into consideration; hence, their placing and contents are briefly summarised (see Seeman 2011:5-6):

- Addition A (precedes MT 1:1): Mordechai has a visionary dream. He struggles to understand it. He hinders an assassination plot against the king. Consequently, he is promoted and the conspirators are punished. Mordechai's promotion gives reason to the fury of Haman.

- Addition B (interpolates MT 2:13-14): The text of Haman's royal edict ordering the execution of the Judeans.

- Addition C (follows MT 4:17): Mordechai and Esther pray for God to deliver the Jews from abolition; Esther also prays for bravery before the king.

- Addition D (replaces MT 5:1-2): Esther passes into the company of the king and faints twice; with divine intervention, the king receives her sympathetically.

- Addition E (interpolates MT 8:12-13): The text of Esther's royal edict accusing Haman of a conspiracy against the

TABLE 1: Macrostructure of LXX-Esther.

\begin{tabular}{lc}
\hline Macrostructure & LXX-Esther \\
\hline 1. Mordechai's dream & A. 1-11 \\
2. The incomplete fulfilment of the dream & A. 12-17 \\
3. The complete fulfilment of the dream & $1: 1-10: 3$ \\
B. The novel & $1: 4-9: 19$ \\
i. Description & $1: 4-2: 23$ \\
ii. The first complication & $3: 1-15+$ B $1-7$ \\
iii. The plan and two new complications & $4: 1-C / D-5: 24$ \\
iv. The crisis & $6: 1-5$ \\
v. The turning point & $6: 6-E-8: 14$ \\
vi. Conclusion & $8: 15-9: 19$ \\
C. Epilogue & $9: 20-31$ \\
D. The conclusion & $10: 1-3$ \\
4. The interpretation of Mordechai's dream & F 1-6a \\
5. Discourse & $6 b-9$ \\
6. The final command & F 10 \\
\hline Source: Du Toit, M., 2008, 'The LXX book of Esther as a satirical drama', Journal for Semitics \\
17(1), 77-95. https://hdl.handle.net/10520/EJC101087
\end{tabular}


king, revoking the execution decree and instructing the commemoration of the 13th of Adar.

- Addition F (follows MT 10:3): Mordechai interprets his dream in the light of the events that have emerged and instructs the commemoration of the 14th and 15th of Adar (in LXX, followed by the colophon).

\section{The hero's departure}

\section{Mordechai's dream (Addition A: 1-11): The scene is created for the hero's departure}

According to Thambyrajah (2019:470-73) and Seeman (2011:3-15), the dream of Mordechai (Addition A) gives warning of adventures to come. It performs the same purpose as did dreams and oracles in Greek novels. The dream in Addition A functions as a narrative hook, and it catches the attention of the readers and encourage them to resume reading. Clues are given of what directions the story will take. The dream proposes a symbolic account of the conflict between Haman and Mordechai. In the dream, he perceives a battle, suggested by fighting serpents or dragons (LXXEsther 1:5). The dream embodies vivid pictures of nature acting in supernatural ways. Reference is made to water, light, darkness, earthquakes, thunder and lightning (LXXEsther 1:6-11). The dream concludes with the Jews' redemption.

The dream in Addition A and the interpretation of this dream in Addition F outline the narrative. Within this outline, the author presents the characters, the plot and the eventual purpose of the narrative, namely, the turnabout of the position of the Diaspora Jews (Du Toit 2008:86). Mordechai's dream suggests the rising of a possible hero who will turn around the dilemma of his or her fellow Jews.

In the course of the hero's journey, Mordechai plays the role of the mentor who provides the hero with the means needed to embark on and continue her journey, similar to the role of the blind seer Tiresias in the second journey of Homer's Odysseus to the underworld. ${ }^{3}$ In Sophocles' drama Oedipus the King (2016), the blind Tiresias confirms the oracle's prediction that Oedipus is predestined to kill his father and marry his mother. Although blind, Tiresias is 'gifted with the wholeness of perspective that comes from a wider range of human experience than is available to other mortals expected to a single gender' (Harris \& Platzner 1997:612). Zeus compensated Tiresias for his physical blindness by giving him the gift of inner sight or prophetic vision.

Mordechai 'sees' coming events in a dream. His ability to see and interpret invents is further highlighted by Addition A (LXX-Esther 12-19). Whilst he took his rest in the courtyard

3.Tiresias informs Odysseus that while he wants 'a sweet smooth journey home' (111), 'a god will make it hard for you' (113). Poseidon is the god who is angry because Odysseus has blinded his son, the Cyclops. Tiresias tells Odysseus that his crew may still reach home. Tiresias says it is critical for Odysseus's crew not to crew may still reach home. Tiresias says it is critical for Odysseus's crew not to disturb the cattle of Helios, the sun god, for if they do, they will be ruined. Even if Odysseus persists, he will 'come home late/and come a broken man' (129-130). His men will be wiped out, and he will find 'a world of pain at home,' with men courting his wife and eating all his food (132). Odysseus needs to 'pay them back in blood (135). After he has taken revenge on the men demolishing his house, he will have to go to a place far from the sea and offer a sacrifice to Poseidon. Simply then will he be able to enjoy a 'gentle, painless death' (154) and know that his land and people are in peace (Book 11, transl. Fagels 2006). with two eunuchs keeping guard in the courtyard, he eavesdropped on their conversation and learned that they were planning to kill king Artaxerxes. After forewarning the king, he, although being a Jew, came to serve the Persian king. With Mordechai's assistance, Esther steps onto the first threshold and leaves behind the familiar to move into the unknown.

\section{Crossing the first threshold into the unknown: Virgin to Concubine (Exposition 1:4-2:23)}

Wetter (2012:331-32) suggests that the treatment of Esther and the other virgins in Esther 2 may be interpreted as a rite of passage, intended to cut off all former social relations and prepare the girls for their life in the royal harem. In the case of rite of passage, the objective is to briefly or permanently change someone's social status. Van Gennep (1960:10-11) identified a special category of rituals, rite of passage, involving three stages: separation (pre-liminal state), transition (liminal state) and incorporation (post-liminal state). The individual experiencing these rituals is separated (often physically) from his or her former self, passes through a phase of alteration in which the old status is dispersed, but not yet substituted by the new, and eventually comes forward as a new individual who has integrated and embodied an altered position in the social and religious hierarchy. The virgins mentioned in the narrative of Esther are entirely cut off from their prior social background (LXX-Esther 2:8). They are consigned to a group of peers, estranged from the rest of society, assigned to the custody of a stranger (LXX-Esther $2: 8)$ and exposed to an extended series of treatments (LXXEsther 2:12). Finally, they come forward bearing the new status of royal concubines.

Esther's introduction to the Persian royal court symbolises the hero's call to embark on an adventure, but she is not the author of her own story. She is separated from her familiar roots and is forced to deny her Jewish identity (LXX-Esther $2: 10,20)$. The rite of passage removes her from what is known and separates her from her previous identity. According to Beal (1995:91-2), Esther's first appearance in front of her readers conceals more than it uncovers. Esther becomes heir to the sexist heritages imposed after Vashti's removal. Whilst Esther performs in the beauty pageant to compete for the position of the king's wife, she is obligated to bare her feminine corporeality. After being examined well, she becomes Artaxerxes' new wife (LXX-Esther 2:15). Employing active verbs contrasting Esther's impassiveness (accentuated by verbs in the passive voice), Artaxerxes demotes her to a bodily object even further. She may see him when summoned (LXX-Esther 4:11) never by own choice or on her terms. Beal (1995:91-2) concludes that laws constructed by a patriarchal society constructed a 'gendered' Esther.

\section{The call to adventure: Complication (3:1-15 + B 1-7)}

The declaration of the king stated in Addition $\mathrm{B}$ depicts a challenging situation for the Jews. It tells of the Edict of Artaxerxes against the Jews. The position of Haman is expressed in detail, whilst the stubbornness of the Jews is 
exaggerated (Addition B, 13:5). Addition B details how Haman, the king's second-in-command:

$[P]$ ointed out to us that among all the nations in the world there is scattered a certain hostile people, who have laws contrary to those of every nation and continually disregard the ordinances of the kings. (13:4)

The nation referred to is obviously the Jews. Therefore, Haman has ordered that (Addition B):

[A]11 [Jews, wives and children included], be utterly destroyed by the swords of their enemies, without pity or restraint, on the fourteenth day of the twelfth month, Adar, of this present year. $(13: 6)$

This situation calls for a hero to act and change events.

\section{Refusal of the call: 4:1-17}

The effect of being simply an object, the king's wife, is manifested in Esther's refusal to give hear to Mordechai's request. He urges her to plea on behalf of the Jews, but she seems oblivious to their fate. Mordechai therefore supplies her with the decree that all Jews should be destroyed without restraint (LXX-Esther 4:8), but she refuses to go to the king and ask for her kin's deliverance. She does not openly bewail the fate of her people in empathy - no ash, no fasting and wailing, no sackcloth for the king's wife. Her comment to Mordechai in LXX-Esther 4:11 focuses on the person of the king. No other verse in the LXX-Esther bears the word 'king' $(\dot{o} \beta \alpha \sigma i \lambda \varepsilon u, \varsigma)^{2}$ as many times as $4: 11$ does.

Why does she lack the courage to risk her own life for the greater good and come to the aid of her people? Fox (1991:62) claims that she is 'concerned for her own safety', and Fuchs (1999:80) charges that she is 'too busy with her make-up and other skin-deep activities'. Berman (2001:651) offers a more plausible answer. He explains Esther's passivity in the light of Simone de Beauvoir's typology of the 'Other'. The 'Other' is not only viewed as an object, but is also eventually treated as an object. In a patriarchal society, women who wish to survive have to render to 'Otherness', thus foregoing subjectivity and a will of her own. By recreating herself to be an object, the 'Other' woman realises her femininity in the eye of the Absolute, Essential male. Because woman is reliant on the Absolute, Essential male for her material security, she is prone to surrender the moral justification of her own existence. She is deprived of heroism, revolt, imagination and creativity. Berman (2001:652) claims that Esther is not spoiled, she is the victim of isolation. She is confined to the walls of the palace and isolated from the world of the Jews. She is not able to rise above herself (Berman 2001:652) and intervene in the lot of her people. Therefore, Esther relates the implications for Mordechai's plan in LXX-Esther 4:11, not only in personal terms but also in legal terms ( $\tau \grave{\alpha} \ddot{\varepsilon} \theta v \eta \pi \dot{\alpha} v \tau \alpha$ $\tau \tilde{\eta} \varsigma \beta \alpha \sigma i \lambda \varepsilon i \alpha \varsigma \gamma l v \omega \sigma \sigma \kappa \varepsilon l$ - all the people of the kingdom knows...). Everyone knows that the law is immutable in nature and should be universally accepted.
Our hero is in obvious need of a supernatural aid, a mentor who connects her with the resources needed to continue her journey. She needs Mordechai who reminds her of and reconnect her with her true identity as a Jew (LXX-Esther $4: 13-4)$.

\section{Mordechai's role as the hero's mentor}

As mentioned before, Mordechai's aid to the hero reminds of the blind Tiresias in Sophocles' Oedipus the King (2016). Oedipus's ignorance of his own identity and the people of Thebes' indifference to the identity of their king's murderer produce illness. In both cases, Oedipus' discovery of the truth has a cathartic effect: the plague is over, Oedipus has completed his voyage of self-discovery and achieved at last a state of wholeness not possible whilst the truth about himself lies hidden (Harris \& Platzner 1997:611). Tiresias is familiar with Oedipus's true identity and leads him through the drama to discover himself and become whole. In the journey on discovering his true identity, Tiresias (Line 316) states: to be wise is to suffer. ${ }^{4}$

These words declared by Tiresias echo Mordechai's warning to Esther. Her refusal to plead for her people will ultimately lead to her own death (LXX-Esther 4:13). Esther is challenged to become the subject and discover herself although it may contain suffering. Now is the time for the hero to step across the second threshold into the unknown, an event awesome in enormity and change. Berman (2001:654) interprets

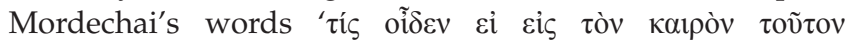
$\dot{\varepsilon} \beta \alpha \sigma i ́ \lambda \varepsilon v \sigma \alpha \varsigma$ - who knows it is not for a time like this you were made to be ruler' (LXX-Esther 4:13) that he has insight into the fact that Esther will be able to embrace the trial set before her only if she engages in restructuring her awareness of her personal history. The refusal to rise to the challenge will also lead to her own destruction. The victim is forced to become the hero and the subject of her own fate.

\section{Crossing the threshold unto the unknown Esther gives hear to Mordechai's plea: Embarking into the belly of the whale}

In 4:16, Esther urges Mordechai 'to gather all the Jews staying in Shushan and fast'. Esther's call for a communal fast in the face of danger recalls the biblical tradition of intercessory fasts in periods of disaster (1 Ki 21:27; Jnh 3:5-8; Neh 9:1). She takes the first step to reconnect with her own identity and subjectivity (Berman 2001:655) by joining ranks with her fellow Jews.

Wetter (2012:330) also emphasises this interpretation of Esther's call for communal fasting. Esther is reunited with her fellow Jews, and simultaneously, the boundary between Jews and the rest of the Persian population is marked. Bach (1997:197) asserts that communal fasts connect the Jewish population of Shushan whilst delineating them as different from the Babylonians through the symbol of food. The fast of the Jews meets the purpose of a counter-balance to the feasts

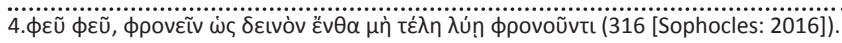


of the Persians. Employing the theories of rituals and rite of passage, Wetter (2012:330-32) interprets the fast as an attempt to reverse the rituals that cut off Esther's ties with her people. The beauty treatment brought a change in Esther's identity. Esther had been severed from her roots, literally by transporting her to a different location, abstractly by sculpting her body to fit a controlled environment. The function of the fast is to undo the effect of these treatments. ${ }^{5}$ This ritual symbolises the first step in our hero's 'coming-out'.

\section{Esther's prayer (Addition C): In the belly of the whale}

Esther's prayer in Addition C reflects the symbolic confirmation of her new identity. She defiles her body moulded to suit the requirements of her role as Persian queen (her first rite of passage) by (Addition C):

$[T]$ aking off her splendid apparel and putting on the garments of distress and mourning, and instead of costly perfumes she covered her head with ashes and dung, and she utterly humbled her body; every part that she loved to adorn she covered with her tangled hair. (17:11)

Her body becomes a metaphor for her new identity and her acceptance of her fate that lies ahead. ${ }^{6}$ This metaphor is elaborated by our hero's declaration that she hates the king's bed, a euphemism for sexual intercourse with a gentile.

These acts of denying her body symbolise our hero's preparation and awareness that she is about to enter into the 'belly of the whale'. She is forced to venture into an unknown world which separates her from her previous identity and subjects her to vulnerability and real danger. Her fear is described in elaborate terms: she was seized by 'deadly

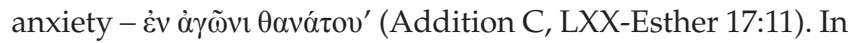
her prayer, she gives language to her true identity by declaring (Addition C):

O my Lord, you only are our king; help me, who am alone and have no helper but you, for my danger is in my hand. Ever since I was born I have heard in the tribe of my family that you, O Lord, took Israel out of all the nations, and our ancestors from among all their forebears, for an everlasting inheritance, and that you did for them all that you promised. (17:12-13)

Harris and Platzner (1997:228) state that the heroic pattern depicts the hero who, in the course of his or her journey, is in due course alienated from his or her fellow human beings and is confronted with horrendous creatures. He or she must also challenge the divine or cosmic powers themselves. His or her journey often concludes into a trip to the Underworld, from which he or she re-appears, conveying a new

5.Wetter (2012:331) concludes, "[a]lthough the ultimate strategist of both the beauty treatments and the fast is the author himself, on the narrative level it seems to be Esther who finally deploys a strategy other than silent submission and who resolutely determines her own religious and ethnic identity'.

6.This interpretation of Esther's body as a metaphor opposes the opinion of Nolte and Jordaan (2009.301): '[i]t can be argued that Esther sees her body as an object something to be used as a means to an end. We are of the opinion that the language something to be used as a means to an end. We are of the opinion that the language used in the narrative by Esther when talking about herself violates her as an individual being. It is an assault on her inherent worth as a person. Nolte and Jordaan (2009.304) further state. "Esther is an apologetic figure. Her self-abasement is an apology for the way she acted, and ultimately for whom she is. It can be argued that she doesn't have a sense of self, other than her social role as a woman in patriarchal society, dominated by the "strict father morality"'. consciousness of himself or herself, his or her limits and his or her relationship with the powers of the universe. Ascending again to the upper world, he or she attains rebirth. Esther's prayer gives voice to an awareness that cosmic powers are at play by declaring that her people's predicament is the cause of their own sin. Their enemies have covenanted with their idols to take them into slavery (Addition C, LXXEsther 17:14). Her God is contrasted with king Artaxerxes who presents himself to be a god. Therefore, Esther invokes her God 'not to surrender his sceptre to what has no being' (Addition C, LXX-Esther 17:15). This reference can be interpreted as an allusion to Esther's statement in 4:11 that 'only if the king holds out the golden sceptre to someone, may that person live'. Artaxerxes' reign 'has no being' as opposed to her Lord, 'King of the gods and Master of all dominions' (Addition C, LXX-Esther 17:16). These words carry witness that the Esther character is aware of cosmic powers and that she has a role to play in the course of cosmic events. In this sense, Esther's prayer is a metaphor for our hero's journey to the underworld and gives witness to her spiritual rebirth.

\section{She thereby asks for courage and (Addition C):}

$[P]$ ut eloquent speech in my mouth before the lion, and turn his heart to hate the man who is fighting against us, so that there may be an end of him and those who agree with him. (17s)

She requests strength to face the lion, the hero's nightmarish creature, and imposes on her God to turn the monster's heart. By interpreting Esther's prayer in the light of the monomyth, it is evident that our hero reclaimed her own identity.

\section{Addition D: The first challenge - Esther confronts the lion}

The contrast between Esther's adornment mentioned in Addition C and Addition D is portrayed in colourful detail. Esther is aware of the effect of her beauty and uses it as a weapon to confront the lion. Esther's body is utilised as a means to an end. The aim is to impress the king with her glorious appearance in order to win his compassion and sympathy for her people. The text states she takes two helpers (maidens) with her, one on whom she relied for support. A hero always has helpers to aid him or her in a challenge.

She confronts the king whilst her heart was filled with fear. Observing the king's terrifying face, Esther fainted. The text then turns to the battle of cosmic powers by mentioning that 'God quickly turned the spirit of the king into humility and distress' (Addition D, LXX-Esther 5:5). The God of the Jews turns the lion into a lamb when the king takes the distressed Esther into his arms and declares: 'What is it Esther, I am your brother, be of good courage!' (Addition D, LXX-Esther 5:4). He orders her to come to him. Addition D ends with the king's words and the text continues to narrate how the king extended his sceptre to her. The God of Israel's aid to Esther is accentuated, he did not surrender his sceptre to Artaxerxes but managed to overrule it (suggested by Esther in Addition C, 17:15). Addition D therefore intensifies the severity of the 
hero's challenge and sets the challenge in the surroundings of a battle between cosmic powers: king Artaxerxes versus the God of Israel. At last the God of Israel steps forward as the conqueror (Carson 2016:34-36).

Artaxerxes effectively offers Esther carte blanche (LXXEsther 5:3), but she only requests that he attends the drinking feast she has arranged. She does not reveal her identity but takes a significant step forward, she becomes the one who is calling. Finally, the object becomes the subject. At the drinking party, she requests Haman's presence at a second party arranged for the next day. The table is set to face her second challenge: confronting the dragon (suggested in Addition A, LXX-Esther 1:5).

\section{The hero faces her second challenge. Slaying the dragon (7:1-10)}

The narrative of Esther's confrontation with the Jews' enemy Haman marks an important stage in our hero's claim to her subjectivity. Esther's divulgence of her true identity is emphasised by what is not written. According to Berman (2001:601), she understands that the key to her success will be to play the card she is familiar with, namely, her consummate 'Other'. Esther casts herself as well as the Jewish people as the 'Other' in order to win the king's favour. In solidarity with her people, she claims that they have no worth and are not named. She never reveals her Jewish roots, but laments her people's predicament. Only after she responds to the king's enquiry about the identity of the offender that she reveals her true identity. Engaging in strategic planning, she slays the dragon - Haman, the Jews' enemy. She expresses her own agenda, but achieves it by accentuating her status as an object.

The second trial also marks the hero's apotheosis. The hero has freed herself from the constraints of her initial world view and attained insight. She trusted on her own emerging skills to step past the crisis. The reward of her 'coming out', the disclosure of her true identity, is the redemption of her people and their respect for her. The king also rewards her with a special gift: she receives the enemy's estate (LXXEsther 8:1). A Jew and a woman owns property in a foreign land. The hero's transformation not only benefits the hero but also aids the community she hails from.

\section{The hero's return: The Jewish queen (8:12-10:3) \\ Addition E: Overturning of the plot}

Addition E narrates that, after Esther succeeds in reversing Haman's treachery, an altered royal decree is issued. It is a reversal of the previous decree (Addition B). The decree states that Haman became bloodthirsty and overconfident because of his position, and strived to kill an 'innocent nation'. Esther is described as the innocent partner of the kingdom of Persia. The Jews are depicted as children of the living and mighty God, governed by virtuous laws. The letter concludes by permitting the Jews to defend themselves against all their aggressors on the 13th day of Adar. The decree highlights the role of Esther, the hero and redeemer of her people. The hero's act of redemption will be commemorated annually by observing the Purim.

\section{Addition F: Mordechai's dream explained}

Addition F (LXX) explains the dream in view of Esther's story (Thambyrajah 2019:488). Mordechai states (Addition F):

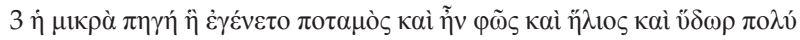

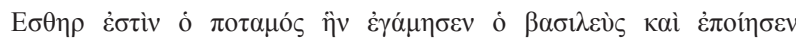



[ 3 And a little spring became a river and there was a light and a sun and much water, Esther is the river, whom the king married and he made her queen. 4 But Haman and I are the two dragons.] (3-4)

Esther is credited for her heroic part in the Jews' redemption. She is described as 'the little spring', an unknown Jewish girl who became a Persian queen and the hero of her people.

\section{Master of two worlds and the freedom to live}

Mordechai wrote letters to all the Jews in king Artaxerxes' provinces ordering them to celebrate the Purim on the 14th and 15th of Adar (LXX-Esther 9:20). This is a day of joy and drinking to commemorate the overturning of the Jews' lot (pur). In verse 9:29, it is stated that 'queen Esther, daughter of Abihail as well as the Jew Mordechai' sanctioned this letter to the Jews. Esther calls upon the authority of her office in addition to that of Mordechai. The communication is dispatched by the queen and daughter of Abihail. This statement emphasises her dualistic identity: her objectivity or 'otherness' as the subordinate wife of king Artaxerxes and her subjectivity as a Jew who fully identifies with her people. The dualistic nature of her identity is never solved. In this sense, our hero is the master of two worlds, both a Jew and a Persian queen.

\section{The metaphor of the hero's story Encouragement to transform}

From the evaluation of the key aspects of the LXX-Esther's narrative, it becomes evident that the entire story of the Esther character fits comfortably into a typical monomyth tripartite structure. The story of the hero's journey is aided by the inclusion of the Additions. Taking Allison and Goethals's (2016:187) remarks into consideration, namely, that a hero story fulfils two basic human functions, an epistemic function and a restorative function, the didactic and healing contents of the hero story are contemplated.

\section{The epistemic function of the hero's story}

Without expounding on the much discussed and complex history of the LXX-Esther, it can be concluded that it was read and retold by Jews living as a marginal party in a largely non-Jewish society (Du Toit 2008:92). Considering the juxtaposition of Esther's history(LXX-Esther 2:6) alongside 
the story of Israel's history, a resemblance is noted. The Jews have no king and no land. They are forced to move to a foreign land and are imperilled by foreigners. Esther is an orphan, forced to be an object. The story of the hero Esther's struggle to reclaim her identity functions as an exemplar for Jews everywhere facing conflicts of loyalty and struggling with identity. An important epistemic function of hero stories exists in their power to shed light on profound life paradoxes (Allison \& Goethals 2016:193-94). Esther's exempla of the ability to live in two worlds, thereby accommodating paradoxes, imparts wisdom, knowledge and skills to the Jews in the Diaspora to survive amidst adversity and conflict.

\section{The restorative function of Esther's heroic story}

Hero stories energise and inspire us. According to Allison and Goethals (2016:194-95), hero stories arouse feelings of elevation that encourage people to become better persons and behave more virtuously. Elevation converts people into believing that they are competent to bring about social transformation. Thus, the restorative function of the Esther's heroic story is to encourage the Jews in the Diaspora to stay true to their identity although they are forced to deny it. They are motivated to act virtuously. Esther had the courage to 'come out' in the face of great adversities and turned out to be the hero of her people. Amidst Hellenistic, mostly male heroes, the Jews lay claim to a Jewish, female hero. The Greeks and Romans celebrated their hero Dionysius' or Bacchus' feast by drinking and celebrating their hero's deliverance from Hades (Harris \& Platzner 1997:197-199). The Jews celebrated their hero Esther's rescue from the lion (Artaxerxes) and the dragon (Haman) and their own consequent survival by commemorating the Purim in a festival atmosphere, with people wearing masks, performing out satirical plays and drinking superfluously.

\section{Conclusion}

The story of the Esther character as portrayed in the LXXEsther's narrative, aided by the inclusion of the Additions, fits comfortably into a typical monomyth tripartite structure. Esther's heroic story is an effective delivery system for conveying complicated truths and for inspiring humans towards a higher emotional and behavioural state, thus fulfilling two basic human functions: an epistemic function and a restorative function. Esther is depicted as an underdog, an 'every (wo)man' who is summoned on a journey presenting exceptional challenges and conclusively steps out as the redeemer of her people. Esther's exempla of accommodating paradoxes imparts wisdom to the Jews in the Diaspora to survive amidst adversity and conflict. The restorative function of the Esther's heroic story is to encourage the Diaspora Jews to stay true to their identity although they are compelled to refute it. Ultimately, Esther's hero story acts as a source of encouragement to restructure and re-story our lives, inspiring us to 'come out' as the heroes of our own unique stories.

\section{Acknowledgements Competing considerations}

The author declares that she has no financial or personal relationships that may have inappropriately influenced her in writing this article.

\section{Author's contribution}

S.M.d.B. is the sole author of this research article.

\section{Ethical considerations}

This article followed all ethical standards for research without direct contact with human or animal subjects.

\section{Funding information}

This research received no specific grant from any funding agency in the public, commercial or not-for-profit sectors.

\section{Data availability}

Data sharing is not applicable to this article as no new data were created or analysed in this study.

\section{Disclaimer}

The views and opinions expressed in this article are those of the author and do not necessarily reflect the official policy or position of any affiliated agency of the author.

\section{References}

Albert, S.W., 1996, Writing from life: Telling your soul's story, G.P. Putnam's Sons, New York, NY.

Allen, N., 2019, '3 Maccabees as a monomyth', HTS Teologiese Studies / Theological Studies 75(3), 1-6, a5497. https://doi.org/10.4102/hts.v75i3.5497

Allison, S.T. \& Goethals, G.R., 2016, 'Hero worship: The elevation of the human spirit', Journal for the Theory of Social Behaviour 46(2), 187-209. https://doi. org/10.1111/jtsb.12094

Bach, A., 1997, Seduction and betrayal in biblical narrative, Cambridge University Press, Cambridge, UK.

Bahar, S., 2012, 'Coming out as queen: Jewish identity, queer theory, and the Book of Esther', Studies in Gender \& Sexuality 13(3), 167-178. https://doi.org/10.1080/15 240657.2012.709134

Balkaran, R., 2017, 'Joseph's journey: Uncovering Israel's unconscious', Journal of Genius and Eminence 2(2), 96-104. https://doi.org/10.18536/jge.2017. 02.2 .2 .10

Beal, T., 1995, 'Tracing Esther's beginnings', in A. Brenner (ed.): A feminist companion to Esther, Judith, and Susanna, pp. 91-106, Sheffield Academic Press, Sheffield.

Beal, T., 1997, The book of hiding: Gender, ethnicity, annihilation and Esther, Rutledge, London.

Berman, J.A., 2001, 'Hadassah bat Abihail: The evolution from object to subject in the character of Esther', Journal of Biblical Literature 120(4), 647-669. https://doi. org/10.2307/3268264

Branch, R.J., 2014, 'Blood on their hands: How heroines in biblical and Apocryphal literature differ from those in ancient literature regarding violence', In die Skriflig/ In Luce Verbi 48(2), Art. \#1771. https://doi.org/10.4102/ids.v48i2.1771

Bray, P., 2018, 'The hero-journey, Hamlet and positive psychological transformation', Journal of Humanistic Psychology 58(5), 525-555. https://doi. org/10.1177/0022167816689357

Campbell, J., 2008, The hero with a thousand faces, Paladin, London.

Carson, J., 2016, God behind the scenes: A look at the book of Esther, viewed 28 August 2020, from https://static1.squarespace.com/static/56412019e4b08c9445a77e1f/ t/56eb20807c65e4a6fb728690/1458249857719/GOD+BEHIND+THE+SCENES. pdf. 
Cousineau, P., 2001, Once and future myths: The power of ancient stories in our lives, Conari Press, York Beach, ME.

Du Toit, M., 2008, 'The LXX book of Esther as a satirical drama', Journal for Semitics 17(1), 77-95. https://hdl.handle.net/10520/EJC101087

Epson, D. \& White, M., 1992, Experience, contradiction, narrative and imagination, Dulwich Centre, Adelaide.

Efthimiades-Keith, H., 2012, 'What makes men and women identify with Judith? A Jungian Mythological perspective on the feminist value of Judith today', HTS Teologiese Studies/ Theological Studies 68(1), Art. \#1267, 9 pages. https://doi. org/10.4102/hts.v68i1.1267

Fuchs, E., 1999, 'Status and role of female heroines in the Biblical narrative', in A. Bach (ed.), Women in the Hebrew Bible, pp. 77-84, Rutledge, New York, NY.

Fox, M., 1991, Ideology and character in the Book of Esther, 2nd edn., Eerdmans, Grand Rapids, MI.

Gardner, A.E., 1984, 'The relationship of the additions to the Book of Esther to the Maccabean crisis', Journal for the Study of Judaism in the Persian, Hellenistic and Roman Period 15(1-2), 1-8. https://doi.org/10.1163/157006384X00015

Hacham, N., 2007, '3 Maccabees and Esther: parallels, intertextuality, and diaspora identity', Journal of Biblical Literature 126(4), 765-785. https://doi.org/10.2307/ 27638467

Harris, S.L. \& Platzner, G., 1997, Classical mythology: Images and insights, Mayfield Publishing Company, Mountain View, CA.

Jobes, K.H., 1996, The alpha-text of Esther: Its character and relationship to the Masoretic Text, Scholars Press, Atlanta, GA.

Jordaan, P.J., 2008, 'Reading Susanna as therapeutic narrative', Journal for Semitic 17(1), 114-128. https://doi.org/10.1080/2222582X.2018.1473715

Jordaan, P.J., 2009, 'The pendulum is never static: Jesus Sira to Jesus Christ on women in the light of Judith, Susanna and LXX Esther', HTS Teologiese Studies/Theological Studies 65(1), Art. \#167, 6 pages. https://doi.org/10.4102/hts.v65i1.167

Jordaan, P.J., 2018, 'Seeds of the church? Silence and the relevance of 2 Maccabees', Journal of Early Christian History 8(1), 3-21.

Lawrence, C.R., 2009, 'Our heroic adventure: Creating a personal mythology', Journal of Creativity in Mental Health 4(3), 263-271. https://doi.org/10.1080/ 15401380903099595
Leeming, D.A., 1981, Mythology, the voyage of the hero, Oxford University Press, New York, NY.

Nolte, S.P. \& Jordaan, P.J., 2009, 'Esther's prayer in additions to Esther: Addition C to LXX Esther - An embodied cognition approach. Septuagint research article', Acto Patristica et Byzantina 20(1), 293-309. https://doi-org.nwulib.nwu.ac.za/10.1080 $/ 10226486.2009 .11879111$

Premingher, A. \& Greenstein, E.L. (eds.), 1986, The Hebrew Bible in literary criticism, The Unger Publishing Company, New York, NY.

Rahlfs, A. (ed.), 1979, Septuaginta, Deutsche Bibelgesellschaft, Stuttgart.

Robertson, D.L. \& Lawrence, C., 2015, 'Heroes and mentors: A consideration of relational-cultural theory and "the hero's journey"', Journal of Creativity in Mental Health 10, 264-277. https://doi.org/10.1080/15401383.2014.968700

Sedgewick, E., 1990, Epistemology of the closet, University of California Press, Berkeley, CA.

Seeman, C., 2011, 'Enter the dragon: Mordecai as agonistic combatant in Greek Esther', Biblical Theology Bulletin 41(1), 3-15. https://doi.org/10.1177/ 0146107910393141

Semeschuk, K., 2018, 'Narrative practice with a feminist leaning', The International Journal of Narrative Therapy and Community Work 1, 31-40.

Sophocles, 2016, Oedipus the King, transl. R. Fagels, Penguin Classics, London.

Steyn, G.J., 2008, "'Beautiful but tough": A comparison of LXX Esther, Judith and Susanna', Journal for Semitics 17, 156-181. https://hdl.handle.net/10520/EJC101083

Thambyrajah, J.A., 2019, 'Mordecai's dream in Esther - The Greek and Latin versions, character, and the tradition of interpretation', Journal for the Study of the Old Testament 43(3), 479-490. https://doi.org/10.1177/0309089218786088

Van Gennep, A., 1960, The rites of passage, Chicago University Press, Chicago, IL.

Wetter, A., 2012, 'In unexpected places: Ritual and religious belonging In the Book of Esther', Journal for the Study of the Old Testament 36(3), 321-332. https://doi. org/10.1177/0309089212437998

White-Crawford, S.A., 1998, Women's Bible commentary, expanded edition with Apocrypha, C.A. Newsom \& S.H. Ringe (eds.), Westminster John Knox Press, Louisville, KY.

Wills, L.M., 1995, The Jew in the court of the foreign king: Ancient Jewish court legends, Fortress Press, Minneapolis, MN. 